\title{
LOCAL TOURIST SATISFACTION WITH THEIR HOLIDAY IN LITHUANIA
}

\author{
Viktorija Grigaliunaite ${ }^{1}$ and Lina Pileliene ${ }^{2}, \mathrm{PhD}$
}

1,2 Vytautas Magnus University

\begin{abstract}
As the importance of tourism is growing worldwide, every country is putting effort to encourage people visiting it. Local municipalities as well as state governments are trying to attract visitors in various ways; however, the emphasis is often put on attracting foreign tourist. This paper contributes to an existing tourism literature by analysing determinants of local tourism satisfaction. The problem that is solved in the manuscript is: what are the factors that influence local tourist satisfaction with their holiday in a country? Hence the paper aims to determine the factors influencing local tourist satisfaction with their holiday in Lithuania. In order to reach the aim, questionnaire survey was provided. After performing structural equation modelling, the general model of local tourist satisfaction with their holiday in Lithuania was composed.
\end{abstract}

Key words: tourist satisfaction, tourist loyalty, local tourism, structural equation modelling. JEL code: L83, M31.

\section{Introduction}

The significance of tourism is undeniable in a contemporary world. Wang L. and Yotsumoto Y. (2019) emphasize that tourism has a positive effects on such areas as economy, society, culture, and environment, because it contributes to GDP, stimulates improvements to infrastructure, the protection and renaissance of culture, and increases in environmental awareness. According to Jian H. et al. (2017), based on the statistics of The World Tourism Organization (UNWTO), it is obvious that the tourism industry can affect the development of the 110 related industries; moreover, a $\$ 1$ increase in value of tourism can lead to a $\$ 4.3$ wealth for the community; afterwards, tourism industry increase in 10 per cent, is promoting the growth of GDP in 0.8 per cent. Moreover, tourism provides numerous benefits for local communities facing affluence of visitors and feeling tourism's effect on their quality of life (Kapera I., 2018).

Despite the growing number of tourists worldwide, starting with 2015 the amount of domestic tourists in Lithuania is decreasing (Statistics Lithuania, 2019). Moreover, the focus on domestic destinations in terms of satisfying demand for holidays is paid less than on the research considering the challenges associated with inbound travel (Davison L. \& Ryley T., 2016). Therefore, this paper contributes to an existing tourism literature by analysing determinants of local tourism satisfaction and solving a scientific problem: what factors affect local tourist satisfaction with their holiday in a country? The aim of this research is to determine the factors affecting local tourist satisfaction with their holiday in Lithuania.

To reach the aim outlined above, four research tasks were set:

1) based on the theoretical model of Lithuanian Tourist Satisfaction Index, to elaborate a questionnaire which enables to assess satisfaction of local tourists' spending their holiday in Lithuania;

2) to provide a questionnaire research with local tourists spending their holiday in Lithuania;

3) to determine main variables having impact on local tourist satisfaction with their holiday in Lithuania;

4) to compose a general model of local tourist satisfaction with their holiday in Lithuania.

Following the set tasks, questionnaire survey was provided. Structural equation modelling (SEM) using partial least squares (PLS) path modelling methodology was performed to analyse the research

\footnotetext{
${ }^{1}$ Tel.: + 37037 327856; fax: + 37037 327857. E-mail address: viktorija.grigaliunaite@vdu.It.

${ }^{2}$ Tel.: + 37037 327856; fax: + 37037 327857. E-mail address: lina.pileliene@vdu.lt.
} 
results. The provided analysis enabled composing the general model of local tourist satisfaction with their holiday in Lithuania.

\section{Research results and discussion \\ 1. Methodology of the research}

In order to accomplish the tasks set, the formerly developed theoretical model of Lithuanian Tourist Satisfaction Index (Pileliene L. and Grigaliunaite V., 2014), which was used as a foundation for creation of The Index of Tourist Satisfaction with Lithuania regarding inbound tourists (Pileliene L. and Grigaliunaite V., 2016), is now applied as a background for creation of the model of local tourist satisfaction with their holiday in Lithuania as well.

As the chosen model is only theoretical in the case of local tourist satisfaction with their holiday in Lithuania, empirical research is necessary to validate its usage in a context of local tourist satisfaction with their holiday in the country. Thus, factors theoretically affecting tourist satisfaction (and loyalty) are: accommodation and catering in destination, activities in destination, natural features, destination aesthetics, environmental preservation, and destination marketing; the main consequence of tourist satisfaction is considered to be loyalty to the destination. The measurement model is a reflective one; 2-4 manifest variables reflect each latent variable. All of the manifest variables as well as questions regarding respondents' demographic characteristics composed the questionnaire. The modified 10-point Likert scale was applied in the questionnaire for statement evaluation. Random sampling method was used (however, only those who indicated that have recently spent their holiday in Lithuania were asked to participate in further research) and 192 respondents formed the research sample. The survey was accomplished on the June, January, and August, 2018. Structural equation modelling with SmartPLS V.3 software by Ringle et al. (2014) was used to provide a statistical analysis.

\section{Research results}

When assessing a reflective measurement model, internal consistency, indicator reliability, convergent validity, and discriminant validity are evaluated. For the evaluation of internal consistency reliability, composite reliability values are estimated. As it can be seen in Table 1, latter values are above 0.7 ; therefore, internal consistency reliability is verified. The values of average variance extracted (AVE) measure are above 0.5 . Thus, convergent validity of the reflective measurement model is verified as well. All of the indicators' loadings are above 0.7 , thus indicator reliability is supported.

Table 1

Values of composite reliability and average variance extracted

\begin{tabular}{|l|c|c|c|}
\hline No & Variable* & Composite Reliability & Average Variance Extracted \\
\hline $\mathbf{1 .}$ & A\&C & 0.947 & 0.899 \\
\hline $\mathbf{2 .}$ & Activities & 0.906 & 0.762 \\
\hline $\mathbf{3 .}$ & Aesthetics & 0.919 & 0.850 \\
\hline $\mathbf{4 .}$ & DM & 0.926 & 0.808 \\
\hline $\mathbf{5 .}$ & EP & 0.876 & 0.780 \\
\hline $\mathbf{6 .}$ & Loyalty & 0.768 & 0.637 \\
\hline 7. & NF & 0.938 & 0.834 \\
\hline $\mathbf{8 .}$ & Satisfaction & 0.890 & 0.729 \\
\hline
\end{tabular}

* A\&C: accommodation and catering, Activities: activities in destination, NF: natural features, Aesthetics: destination aesthetics, EP: environmental preservation, DM: destination marketing.

Source: author's elaboration 
The criteria of Cross Loadings and Fornell-Larcker criterion allow evaluation of the discriminant validity. Based on the criterion of Cross Loadings, discriminant validity ir verified. Fornell-Larcker criterion (see Table 2) allows verifying the same. Consequently, it could be stated that model exhibits discriminant validity. Thus, the questionnaire is judged to be reliable and valid.

Table 2

Fornell-Larcker criterion

\begin{tabular}{|l|c|c|c|c|c|c|c|c|}
\hline \multicolumn{1}{|c|}{ Variable* } & A\&C & $\begin{array}{c}\text { Activitie } \\
\text { S }\end{array}$ & Aesthetics & DM & EP & Loyalty & NF & $\begin{array}{c}\text { Satisfactio } \\
\mathbf{n}\end{array}$ \\
\hline A\&C & 0.948 & & & & & & & \\
\hline Activities & 0.758 & 0.873 & & & & & & \\
\hline Aesthetics & 0.763 & 0.810 & 0.922 & & & & & \\
\hline DM & 0.794 & 0.855 & 0.808 & 0.899 & & & & \\
\hline EP & 0.722 & 0.646 & 0.602 & 0.667 & 0.883 & & & \\
\hline Loyalty & 0.635 & 0.623 & 0.613 & 0.642 & 0.559 & 0.798 & & \\
\hline NF & 0.568 & 0.569 & 0.586 & 0.646 & 0.408 & 0.475 & 0.913 & \\
\hline Satisfaction & 0.742 & 0.665 & 0.736 & 0.754 & 0.668 & 0.644 & 0.547 & 0.854 \\
\hline
\end{tabular}

${ }^{*} A \& C$ : accommodation and catering, Activities: activities in destination, NF: natural features, Aesthetics: destination aesthetics, EP: environmental preservation, DM: destination marketing.

Source: author's elaboration

The values of the coefficient of determination $\left(R^{2}\right)$ of the variables' satisfaction and loyalty are respectively 67.3 and 50.2 percent; thus, large to moderate. Endogenous latent variables' StoneGeissers' $Q^{2}$ values are exceeding zero, hence, model displays predictive relevance. Additionally, VIF values are below 5 proving No existence of multicollinearity.

The values of the path coefficients in the structural model are provided in Table 3 below. Results show that accommodation and catering has directly positively and statistically significantly impact tourist satisfaction. Nevertheless, the influence of accommodation and catering on loyalty is nonsignificant. Activities in destination has No statistically significant influence neither on tourist satisfaction nor on tourist loyalty. Destination aesthetics statistically significantly impacts tourist satisfaction. Despite this, the influence of destination aesthetics on tourist loyalty is non-significant. Destination marketing has significant effect on tourist satisfaction, but the effect of destination marketing on tourist loyalty is non-significant. Likewise, environmental preservation has direct positive and statistically significant effect on tourist satisfaction, but the influence of environmental preservation on tourist loyalty is non-significant. Natural features have No significant influence neither on tourist satisfaction nor on tourist loyalty. Finally, tourist satisfaction makes a significant impact on tourist loyalty.

Hence, activities in destination and natural features do not affect local tourist satisfaction with their holiday in Lithuania or loyalty to the holiday in Lithuania. Accommodation and catering, destination aesthetics, destination marketing, and environmental preservation affect local tourist satisfaction with their holiday in Lithuania, but do not impact local tourist loyalty to spend holiday in Lithuania. Local tourist loyalty to their holiday in Lithuania is influenced only by their satisfaction with their holiday in Lithuania. Nevertheless, as local tourist satisfaction with their holiday in Lithuania is influenced by accommodation and catering, destination aesthetics, destination marketing, and environmental preservation and tourist loyalty is influenced by tourist satisfaction, the assumption can be made that accommodation and catering, destination aesthetics, destination marketing, and environmental preservation influence tourist loyalty indirectly, with satisfaction as a mediator variable. 
Path coefficients and their statistical significances

\begin{tabular}{|l|c|c|c|c|c|c|}
\hline \multicolumn{1}{|c|}{ Variables* } & $\begin{array}{c}\text { Path } \\
\text { Coefficient }\end{array}$ & S.D. & C.I. Low & C.I. Up & $\begin{array}{c}\text { T } \\
\text { Statistics }\end{array}$ & p Values \\
\hline A\&C -> Loyalty & 0.135 & 0.123 & -0.095 & 0.365 & 1.097 & 0.273 \\
\hline $\begin{array}{l}\text { A\&C -> } \\
\text { Satisfaction }\end{array}$ & 0.202 & 0.092 & 0.038 & 0.392 & 2.200 & 0.028 \\
\hline $\begin{array}{l}\text { Activities -> } \\
\text { Loyalty }\end{array}$ & 0.168 & 0.119 & -0.058 & 0.394 & 1.408 & 0.160 \\
\hline $\begin{array}{l}\text { Activities -> } \\
\text { Satisfaction }\end{array}$ & -0.184 & 0.103 & -0.366 & 0.025 & 1.787 & 0.075 \\
\hline $\begin{array}{l}\text { Aesthetics -> } \\
\text { Loyalty }\end{array}$ & 0.044 & 0.146 & -0.223 & 0.343 & 0.299 & 0.765 \\
\hline $\begin{array}{l}\text { Aesthetics -> } \\
\text { Satisfaction }\end{array}$ & 0.305 & 0.113 & 0.094 & 0.540 & 2.714 & 0.007 \\
\hline DM -> Loyalty & 0.064 & 0.173 & -0.249 & 0.458 & 0.371 & 0.711 \\
\hline DM -> Satisfaction & 0.316 & 0.128 & 0.076 & 0.540 & 2.477 & 0.014 \\
\hline EP -> Loyalty & 0.084 & 0.114 & -0.141 & 0.316 & 0.737 & 0.462 \\
\hline EP -> Satisfaction & 0.221 & 0.076 & 0.076 & 0.367 & 2.917 & 0.004 \\
\hline NF -> Loyalty & 0.057 & 0.087 & -0.126 & 0.232 & 0.658 & 0.511 \\
\hline NF -> Satisfaction & 0.064 & 0.066 & -0.051 & 0.205 & 0.966 & 0.335 \\
\hline $\begin{array}{l}\text { Satisfaction -> } \\
\text { Loyalty }\end{array}$ & 0.265 & 0.124 & 0.024 & 0.478 & 2.129 & 0.034 \\
\hline
\end{tabular}

*A\&C: accommodation and catering, Activities: activities in destination, NF: natural features, Aesthetics: destination aesthetics, EP: environmental preservation, DM: destination marketing.

Source: author's elaboration

Despite this, path coefficients that are non-significant do not support a hypothesized relationship, thus should be omitted from the final model (Hair et al., 2011). Consequently, after the elimination of the non-significant path coefficients and the verification of the model's reliability and validity, final model is elaborated. The values of the coefficient of determination $\left(R^{2}\right)$ of the variables' satisfaction and loyalty in the final model are respectively 66.3 and 41.3 percent; thus, the amount of explained variance of latter variables is still large to moderate. Final model is expressed with structural equations:

Satisfaction $=0.199$ Accommodation and catering +0.260 Destination aesthetics +0.198 Environmental preservation +0.254 Destination marketing

$$
\text { Loyalty }=0.642 \text { Satisfaction }
$$

As it can be seen from the equations, destination aesthetics and destination marketing have the highest influence on local tourist satisfaction with their holiday in Lithuania. Moreover, accommodation and catering and environmental preservation have very similar impact on local tourist satisfaction with their holiday in Lithuania. Finally, improving local tourist satisfaction with their holiday in Lithuania give rise to enhanced tourist loyalty.

To assess the performance of determinants of tourist satisfaction, an importance - performance map is provided in Figure 1 below. The importance of the variable to satisfaction is revealed by variable's total effect (in this case total effect is equal to path coefficient) and the performance of the variables is provided on a scale of 0 to 100 , where zero means the lowest and kindred - the highest performance. 


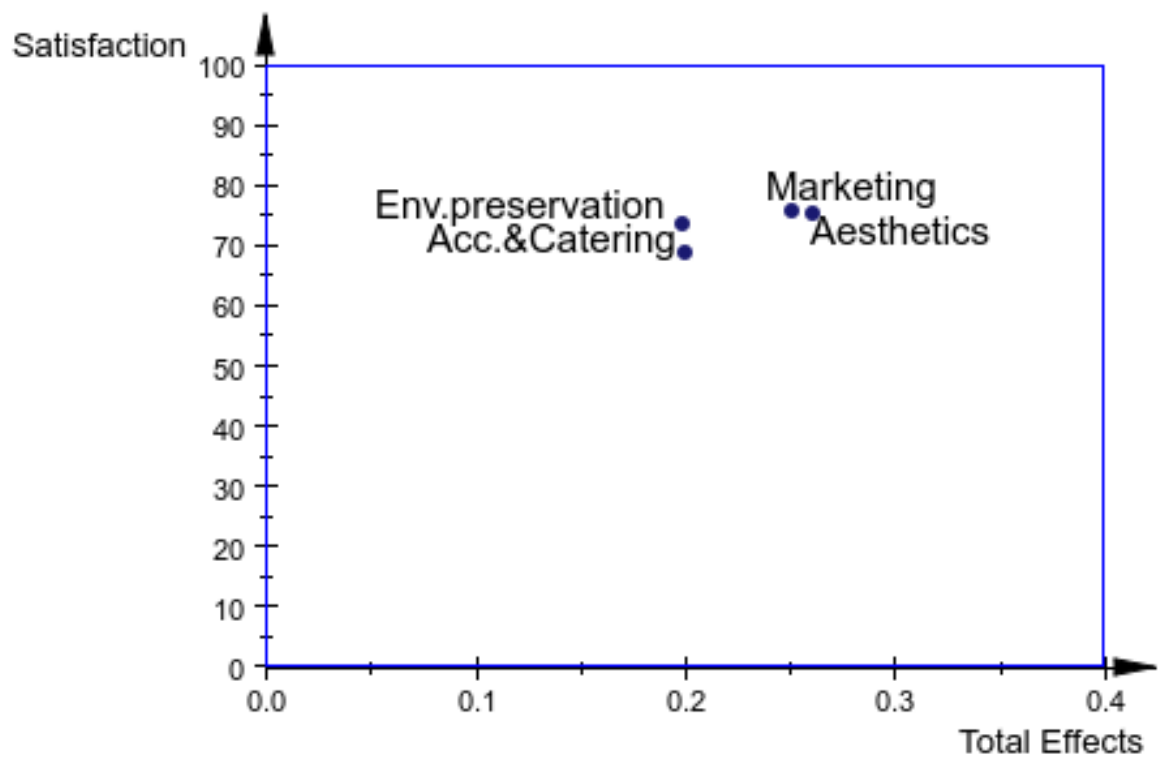

Source: author's elaboration

Fig. 1. Importance - performance map

As it can be seen, the performance of accommodation and catering is the lowest (69.287 points). The performance of environmental preservation is 74.068 points. The two variables, namely destination aesthetics and destination marketing, that have the highest influence on local tourist satisfaction with their holiday in Lithuania have the highest performance points as well, respectively 75.813 and 76.168 points. Hence, it could be stated that accommodation and catering should be improved in order to enhance tourist satisfaction with their holiday in Lithuania.

\section{Discussion}

The analysis of the research results lead to the determination of the core variables impacting local tourist satisfaction with their holiday in Lithuania. Latter variables are determined to be: accommodation and catering, destination aesthetics, environmental preservation, and destination marketing. Moreover, local tourist satisfaction with their holiday in Lithuania influences their loyalty to Lithuania in terms of the intention to recommend and / or spend holiday in this country. Considering these results, the model of local tourist satisfaction with their holiday in Lithuania is constructed and presented in Figure 2.

As the elaborated model reveals, for the local tourists to be satisfied with their holiday in Lithuania, their expectations have to be met or exceeded regarding the variables that influence tourist satisfaction. Nevertheless, the performance of accommodation and catering is evaluated the lowest, hence the assumption could be made that tourist expectations are not met regarding accommodation and catering during holidays in Lithuania. Thus, this variable should be improved. Moreover, destination aesthetics and destination marketing have the highest influence on local tourist satisfaction with their holiday in Lithuania. Despite the fact that the performance of latter variables is relatively good, the assumption could be made that improvement of latter variables could result in competitive advantage as these variables make the biggest impact on satisfaction, which in turn influences loyalty. 


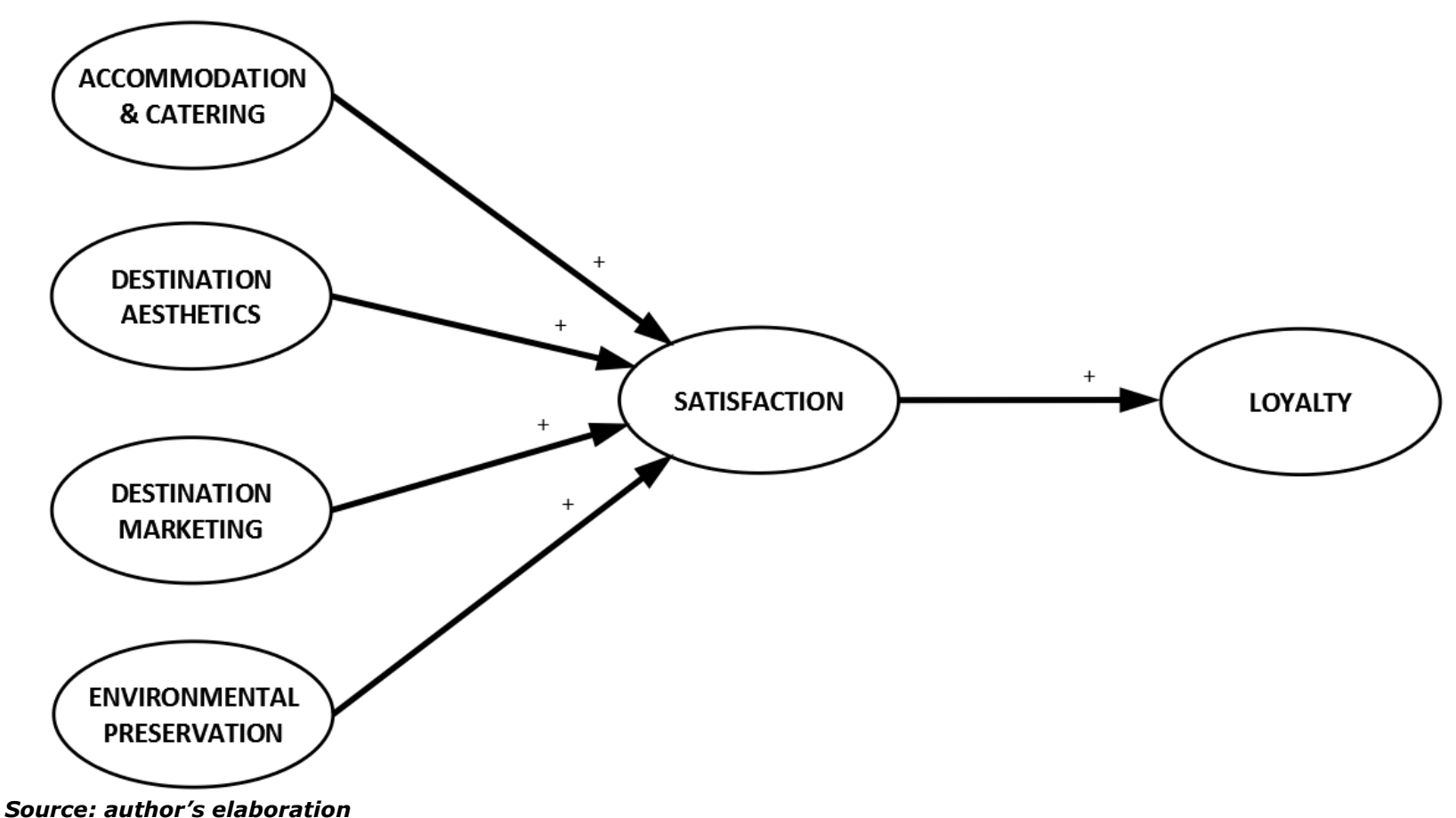

Fig. 2. The model of local tourist satisfaction with their holiday in Lithuania

The elaborated model of local tourist satisfaction with their holiday in Lithuania and evaluation of the performance of model's variables enabled the elaboration of guidelines for the enhancement of local tourist satisfaction with their holiday in Lithuania, which in turn can influence local tourist loyalty to Lithuania as their holiday destination.

\section{Conclusions, proposals, recommendations}

1) The research results contribute to an existing theory on tourist satisfaction. After analysing the respondents' evaluations of factors that are supposed to affect tourism satisfaction with their holiday and tourist loyalty to a destination, strong divergences from theory were observed. Based on the determined structural relations, the general model of local tourist satisfaction with their holiday in Lithuania was composed.

2) The analysis of research results indicated the absence of impact of activities in destination and natural features on local tourist satisfaction with their holiday in Lithuania. The factors that have to be considered while achieving to increase local tourist satisfaction with their holiday in their homeland were found to be accommodation and catering, destination aesthetics, destination marketing, and environmental preservation. Latter factors have to be monitored and managed in order to increase the local tourist satisfaction.

3) Based on the analysis of the research results the conclusion is made that tourist expectations are not met regarding accommodation and catering during holidays in Lithuania. Thus, this variable should be improved as much as possible. Additionally, despite the fact that the performance of destination aesthetics and destination marketing is relatively good, the conclusion is made that improvement of latter variables could result in competitive advantage as these variables make the biggest impact on satisfaction.

4) None of analysed factors had an impact on local tourist loyalty in terms of spending their holiday in Lithuania. Results indicated that tourist loyalty could be affected only by increasing their satisfaction. Considering the contradiction with theory, further research has to be provided in 
order to determine more determinants of tourist loyalty in terms of spending holiday in their home country.

\section{Bibliography}

1. Davison, L., Ryley, T. (2016). An examination of the role of domestic destinations in satisfying holiday demands. Journal of Transport Geography. Volume 51, February, pp. 77-84.

2. Hair, J.F., Ringle, C.M., Sarstedt, M. (2011). PLS-SEM: Indeed a Silver Bullet. Journal of Marketing Theory and Practice. Volume 19, Issue 2. pp. 139-152.

3. Jian, H., Pan, H., Xiong, G., \& Lin, X. (2017). The Impacts of Civil Airport layout to Yunnan Local Tourism Industry. Transportation Research Procedia. Volume 25, 2017, pp. 77-91.

4. Kapera, I. (2018). Sustainable Tourism development efforts by local governments in Poland. Sustainable Cities and Society. Volume 40, July, pp. 581-588.

5. Pileliene, L., Grigaliunaite, V. (2014). Lietuvos turistu pasitenkinimo indekso modelis: teorines izvalgos. (Lithuanian tourist satisfaction index model: theoretical aspects). Organizaciju vadyba: sisteminiai tyrimai. No. 69. pp. 107-118.

6. Pileliene, L., Grigaliunaite, V. (2016). The index of tourist satisfaction with Lithuania. European Journal of Tourism, Hospitality and Recreation. Volume 7, Issue 1. pp. 30-39.

7. Ringle, Ch. M., Wende, S., Becker, J.-M. (2014). Smartpls 3. Hamburg: SmartPLS. Retrieved: http://www.smartpls.com.

8. Statistics Lithuania (2019). Domestic Tourism Statistics. Retrieved: https://osp.stat.gov.It/statistiniurodikliu-analize?hash=91fa411f-af8c-43cf-b99f-3e8cf23ef630\#/. Access: 15.01.2019.

9. Wang, L., Yotsumoto, Y. (2019). Conflict in tourism development in rural China. Tourism Management. Volume 70, February, pp. 188-200. 